\title{
The effects of diazepam on the elevated T-maze are dependent on the estrous cycle of rats
}

\author{
Amauri Gouveia $\mathrm{Jr}^{1}$, Gabriela Antunes ${ }^{2}$, Caio Maximino ${ }^{1}$ and Silvio Morato ${ }^{3}$ \\ 1 Universidade Federal do Pará, Brazil \\ 2 Okinawa Institute of Science and Technology, Japan \\ 3 Universidade de São Paulo, Brazil
}

\begin{abstract}
In order to determine the modulation of anxiolytic and panicolytic-like effects of diazepam by the hormonal cycle of female rats, male and female rats - the latter divided per estrous cycle phase (estrus, diestrus, metaestrus and proestrus) - were tested in the elevated T-maze, a behavioral model of panic and anxiety. Diazepam $(0.5,1.0$ and $2.0 \mathrm{mg} / \mathrm{kg})$ or saline solution was injected in individual animals that were submitted to one session in the elevated T-maze 25 min after drug/saline administration. The test consisted of three avoidance trials and one escape trial, separated by a $30 \mathrm{~s}$ interval, during which the animals were isolated in individual cages. The avoidance trials began with the animal being placed at the end of the maze's enclosed arm. The time necessary for the animal to leave the central square was considered as the response's latency. The trials that exceeded $300 \mathrm{~s}$ were considered as failures. Results demonstrate a decrease in the effects of diazepam in inhibitory avoidance (anxiety) trials in females in diestrus and proestrus, but no relation of gender or estrous cycle on diazepam effects on escape trials (fear). The results support the hypothesis that down-regulation of $\mathrm{GABA}_{\mathrm{A}}$ receptors by activation of nuclear estrogen receptors and induction of PKC-mediated GABA $A_{A}$ receptor phosphorylation by activation of surface estrogen receptors in raphe neurons underlie the modulation of diazepam sensitivity by estrogen. Keywords: diazepam, estrous cycle, estrogen, anxiety, elevated T-maze.
\end{abstract}

Received 17 July 2009; received in revised form 21 September 2009; accepted 10 November 2009. Available on line 29 December 2009.

\section{Introduction}

Anxiety is an emotional state that emerges under situations in which risk is probable, but not certain. This state is associated with behaviors linked to defense reactions, that is, a set of species-specific behavioral strategies which were selected in evolutionary history to increase the possibilities of survival in dangerous situations as well as the autonomic activation that accompanies these behaviors in danger situations, such as cautious investigation (Blanchard \& Blanchard, 1988; Fanselow \& Lester, 1988).

Amauri Gouveia Jr and Caio Maximino, Laboratório de Neurociências e Comportamento, Instituto de Ciências Biológicas, Universidade Federal do Pará, Belém, Brazil. Gabriela Antunes, Okinawa Institute of Science and Technology, Okinawa, Japan. Silvio Morato, Laboratório de Comportamento Exploratório, Departamento de Psicologia e Educação, Faculdade de Filosofia, Ciências e Letras de Ribeirão Preto, Universidade de São Paulo, Ribeirão Preto, São Paulo, Brazil. Correspondence regarding this article should be directed to: Amauri Gouveia Jr. - Laboratório de Neurociências e Comportamento, Instituto de Ciências Biológicas, Universidade Federal do Pará, Rua Augusto Corrêa 01, 6608-180, Belém/PA, Brazil. E-mail: agjunior@ufpa.br
In humans, anxiety is manifested by clinical alterations with variable severity distributed along the anxiety spectrum, and is usually treated with benzodiazepines, a class of substances that act on the $\mathrm{GABA}_{\mathrm{A}}$ receptor complex by allosteric modulation.

GABA is a neurotransmitter of mostly inhibitory action that is present in about $30 \%$ of the synapses in the central nervous system (Olsen, 2002). The GABA receptor complex prevails on mammalian nervous systems; it receives, besides the endogenous GABA neurotransmitter, benzodiazepines, barbiturates and other anxiolytic drugs, hormones and anticonvulsants (Berezhnoy, Gravielle, \& Farb, 2007; Schmitt, Luddens, \& Hiemke, 2000). Most ligands which modulate $\mathrm{GABA}_{\mathrm{A}}$-associated chloride currents seem to act through allosteric modulation of the opening of a chloride channel, altering the probability that this ligand-gated channel is in an "open" state (Berezhnoy et al., 2007; Costa, 1998; Olsen, 2002). The actions of GABA at the many $\mathrm{GABA}_{\mathrm{A}}$ receptor subtypes can also be agonized or allosterically modulated by a variety of progesterone metabolites (Puia et al., 1990). Neurosteroids given in high doses can gate chloride channels associated with GABA $_{\mathrm{A}}$ receptors even in the absence of GABA (Puia, Ducic, Vicini, \& Costa, 1993), an effect that has been 
observed with barbiturates, but not benzodiazepines (Costa, 1998). Progesterone derivatives positively modulate GABA action on $\mathrm{GABA}_{\mathrm{A}}$ receptors (Puia et al., 1993); pregnelone sulfate (a progesterone derivative) negatively modulates chloride currents gated by GABA only in high concentrations (Puia et al., 1993). Interestingly, this neurosteroid is most efficient in its GABA-potentiating action in recombinant receptors including the $\gamma_{1}$ subunit - a subunit whose mRNA is expressed predominantly in native $\mathrm{GABA}_{\mathrm{A}}$ receptors located in glial cells (McKernan \& Whiting, 1996).

Besides the direct action of progesterone metabolites on $\mathrm{GABA}_{\mathrm{A}}$ receptors, estrogen has also been implicated in the regulation of $\mathrm{GABA}_{\mathrm{A}}$ receptor activity (Bitran \& Dowd, 1995; Guilinello, Gong, Li, \& Smith, 2001; Hamon et al., 1983; Herbison, 1997; Herbison \& Fénelon, 1995; Zhu \& Vicini, 1997), despite the lack of evidence to suggest that this steroid is a direct allosteric modulator of the $\mathrm{GABA}_{\mathrm{A}}$ receptor. A major contributing factor in the wide array of behaviors which are mediated by estrogen and progesterone is the existence of two different estrogen receptors in the brain: Estrogen Receptor- $\alpha$ (ER- $\alpha)$ and Estrogen Receptor- $\beta$ (ER- $\beta)$. In rodent brains, the first are expressed strongly in hypothalamic nuclei which are closely related to reproductive physiology, as well as in the pons and medulla (Österlund, Kuiper, Gustafsson, \& Hurd, 1998; Shughrue \& Merchenthaler, 2001). ER- $\beta$, however, is expressed widely in the forebrain (neocortex as well as limbic forebrain cell nuclei) and raphe (Österlund, Gustafsson, Keller, \& Hurd, 2000; Österlund et al., 1998; Shughrue \& Merchenthaler, 2001; Silveira, Zangrossi, Viana, Silveira, \& Graeff, 2001). Consistent with this distribution, for example, mice which were knocked out of either ER- $\alpha$ or ER- $\beta$ demonstrated differences in exploratory behavior and activity levels: while ER- $\alpha$ $\mathrm{KO}$ mice presented differences in spontaneous wheel running, ER- $\beta \mathrm{KO}$ mice had an anxious phenotype (Krezel, Dupont, Krust, Chambon, \& Chapman, 2001; Ogawa, Chan, Gustafsson, Korach, \& Pfaff, 2003), with decreased exploration of the center of an open-field (OF) and decreased exploration of the open arms of an elevated plus-maze.

The estrous cycle of rodents lasts for about four to five days, and has four phases, denominated estrus, metaestrus, diestrus and proestrus. Estrus corresponds to ovulation, and progesterone is found at its peak level during this phase. Metaestrus corresponds to the phase between cycles, and hormone levels are restored to the "baseline" level in the vagina. At the end of the metaestrus phase, the diestrus phase begins, a period where estrogen's action takes place. Proestrus corresponds to the peak on the action of estrogens.

Many studies explored the different phases of the estrous cycle in relation to fear and anxietylike behavior, focusing mainly on estrus (the phase in which progesterone is highest) and proestrus (the phase in which estrogen is highest) (for a review, cf. Morgan, Schulking, \& Pfaff, 2004). John Archer (1975) observed that females in estrus not only have an increase in behaviors involving gross motor activity, but also are more reactive to fearful stimuli. In terms of conditioned fear, females in proestrus acquire eye-blink responses faster than females in other stages (Shors, Lewczyk, Pacynski, Mathew, \& Pickett, 1998), exhibit facilitated acquisition of twoway avoidance (Sfikakis, Spyraki, Sitaras, \& Varonos, 1978) and less freezing to context in a Pavlovian fear conditioning paradigm (Markus \& Zecevic, 1997). Cycling female rats in proestrus or estrus show less activity in the open-field than females in other stages (Díaz-Véliz, Benavides, Butrón, Dussabaut, \& Mora, 1999), which the authors interpreted as a measure of increased fear. Another study (Frye, Petralia, \& Rhodes, 2000) reported that female rats in proestrus and estrus were more active in the periphery of the OF (i.e., increased thigmotaxis) but not in the center, which is a less controversial measure of anxiety (Treit \& Fundytus, 1989). These differences were associated with increased hippocampal content of progesterone and $3 \alpha, 5 \alpha$-THP. The latter results are partially contradictory with observations by Rhodes and Frye (2001) that the inhibition of progesterone metabolism in the hippocampus during estrus had pro-exploratory and antinociceptive effects, also producing an anxiogenic profile. To complicate matters further, in the elevated plus-maze (EPM), females in proestrus present decreased anxiety (Frye et al., 2000; Gouveia \& Morato, 2002; Mora, Dussabaut, \& Díaz-Véliz, 1996; Nomikos \& Spyraki, 1988). Morgan and colleagues (2004) argued that these differences could be accounted for by different dependencies on ER- $\alpha$ or ER- $\beta$ receptors, as well as the different neuroanatomical patterns of expression for both receptors. In addition, one could argue that the modulation exerted by estrogen and progesterone is widespread in different systems which mediate anxiety, such as GABA (Bitran \& Dowd, 1995; Hamon et al., 1983; Herbison, 1997; Herbison \& Fénelon, 1995; Maggi \& Perez, 1984), serotonin (FernándezGuasti, Martínez-Mota, Estrada-Camarenas, Contreras, \& Lórez-Rubalcava, 1999; Le Saux \& Di Paolo, 2005; Maswood, Stewart, \& Uphouse, 1995; Maswood, Truitt, Hotema, Caldarola-Pastuszka, \& Uphouse, 1999; Österlund, Hallin, \& Hurd, 2000; Robichaud \& Debonnel, 2005; Rubinow, Schmidt, \& Roca, 1998), oxytocin (Dellovade, Zhu, \& Pfaff, 1999; Koksma et al., 2003), and protein kinase CE (Fancsik, Linn, \& Tasker, 2000; Hodge et al., 2002).

The elevated T-maze is an anxiety and memory animal model developed from the classic elevated plus-maze by the elimination of one of the maze's 
enclosed arms. In relation to other animal models, the elevated T-maze allows the differentiation between the behavioral elements that compose generalized anxiety, fear, and learned anxiety, based on the animal's natural aversion to open and elevated spaces, thus enabling clearer discriminations between the anxiolytic and panicolytic effects of diverse drugs (Bueno, Zangrossi, \& Viana, 2007; Graeff, Viana, \& Tomaz, 1993; Zangrossi \& Graeff, 1996): while inhibitory avoidance of the open arm is supposed to represent learned fear, the escape response from the open arm would represent innate fear. Anxiolytic-like effects are observed in the impairment of inhibitory avoidance, while impairment of escape responses is associated with panicolytic-like effects (Graeff et al., 1993; Zangrossi \& Graeff, 1996). Diazepam selectively impairs inhibitory avoidance in the elevated T-maze, leaving escape responses unchanged (Graeff, Netto, \& Zangrossi, 1998; Graeff et al., 1993; Viana, Tomaz, \& Graeff, 1994; Zangrossi \& Graeff, 1996). In a previous work (Gouveia, dos Santos, Felisbino, Afonseca, Antunes, \& Morato, 2004), we demonstrated that the estrous cycle modulates different parameters of conditioned and unconditioned fear in this model, with females in proestrus and estrus showing impairment in the acquisition of inhibitory avoidance but no alterations in escape, while females in diestrus showed increased baseline anxiety. In the present work, we assessed the effects of the estrous cycle on benzodiazepine sensitivity of rats using the elevated T-maze model.

\section{Methods}

\section{Subjects}

Thirty-two male rats and 128 female rats (Rattus novergicus, Wistar, UNESP, Botucatu) were used in the experiment. Animals were distributed in groups $(n=$ 8) based on sex, drug dose and (in the case of females) estrous cycle phase. Subjects were kept in collective cages (five per cage) in the same room with ad libitum water and food, as well as controlled light/dark cycle (12L:12D, lights on at 0700$)$ and temperature $\left(25^{\circ} \mathrm{C} \pm 2^{\circ} \mathrm{C}\right)$.

\section{Apparatus}

The elevated T-maze consisted of two opposed open arms $(50 \times 10 \mathrm{~cm})$ and one enclosed arm (50x10x40 cm), perpendicular to the other two. The maze's arms bind to a $10 \times 10 \mathrm{~cm}$ central area. The apparatus was elevated $50 \mathrm{~cm}$ above the ground. The whole maze was made of wood and the surfaces of its arms were covered with formica.

\section{Drug}

Diazepam (0.5, 1.0 and $2.0 \mathrm{mg} / \mathrm{kg}$, Roche Products Ltd., Brazil) was dissolved in saline solution (0.9\%) as served as control solution. Diazepam and control solution were injected intraperitoneally at a total volume of $4 \mathrm{ml} / \mathrm{kg}$.

\section{Procedure}

Initially, females had their estrous cycle recorded with daily collection of vaginal material for a period that varied between 5-6 days. Females with an irregular cycle were discarded. After verification, the animals were divided in groups based on sex, and females were divided in subgroups according to the phase of their estrous cycle (estrus, diestrus, metaestrus or proestrus). Further subdivision was made as animals were divided according to drug dosage (saline; 0.5; 1.0; and $2.0 \mathrm{mg} /$ $\mathrm{kg}$ ), resulting in nested groups with eight animals each. Each experimental subject underwent a single test session that began 25 minutes after the intraperitoneal injection of diazepam.

The test consisted of three avoidance trials and one escape trial separated by $30 \mathrm{~s}$ intervals in which the animals were isolated in individual cages. The avoidance trials began with the animal being placed at the end of the maze's closed arm. The time necessary for the animal to leave the central square was considered as the response latency. Trials that exceeded $300 \mathrm{~s}$ were considered as failures. After the inhibitory avoidance test, an escape test was executed, where the animal was placed at the end of the right open arm and the latency time to cross the central square was recorded. Thus, latencies to leave the compartment in which the animal was first placed were the outcome assessed in both inhibitory avoidance and escape trials.

The maze was cleaned after each session to avoid interference of the odor of a previously tested animal on the behavior of the animal observed on the following session.

The experiments were performed in compliance with the recommendations of the SBNeC (Brazilian Society for Neuroscience and Behavior), which are based on NIH's Guide for Care and Use of Laboratory Animals. Procedures and animal housing conditions were approved by the UNESP Research Ethics Committee.

\section{Statistical analysis}

Data are presented as means \pm S.E.M. The results of the inhibitory avoidance trials were analyzed with a twoway repeated measure analysis of variance (betweensubjects factors: dose and hormonal state; withinsubjects factor: trial). Data from the escape trials were analyzed with a two-way analysis of variance (betweensubjects factors: dose and hormonal state). Tukey posthoc tests were performed whenever appropriate, and statistically significant $p$-values were set as $\leq .05$.

\section{Results}

Figure 1 presents latency times to leave the closed arm, a measure of inhibitory avoidance, across trials. As expected, latency times increased monotonically as trials occurred, irrespective of estrous cycle phase or drug dose. However, this relationship was broken in 
diestrus females taking the $2.0 \mathrm{mg} / \mathrm{kg}$ dose.

Since the data presented statistically significant sphericity ( $\mathrm{W}=.876, \mathrm{p}<.005)$, all subsequent analyses assumed sphericity. Within-subjects main effects of trial number $\left(\mathrm{F}_{[2,280]}=92.067, \mathrm{p}<.005\right)$ and dose within trial $\left(\mathrm{F}_{[6,280]}=4.313, \mathrm{p}<.005\right)$ were found, but hormonal state did not exert significant effects on this variable $\left(\mathrm{F}_{[8,280]}=1.667, \mathrm{p}=.106\right)$. No interaction between dose and hormonal state was found within trial number $\left(\mathrm{F}_{[24,280]}=1.276, \mathrm{p}=.179\right)$.
Diazepam doses $\left(\mathrm{F}_{[3,140]}=3.842, \mathrm{p}=.011\right)$ and hormonal status $\left(\mathrm{F}_{[4,140]}=3.363, \mathrm{p}=.012\right)$ produced main between-subject effects on the mean latency times, and an interaction between both factors $\left(\mathrm{F}_{[12,140]}=4.514\right.$, $\mathrm{p}<.005$ was also observed. Post-hoc tests discriminated the underlying differences; the results of these analyses can be found in Figure 1.

Figure 2 presents the effects of diazepam and gender/ hormonal status on the latency to exit the central square. No main effects of diazepam dose $\left(\mathrm{F}_{[3,140]}=1.666, \mathrm{p}=.34\right)$
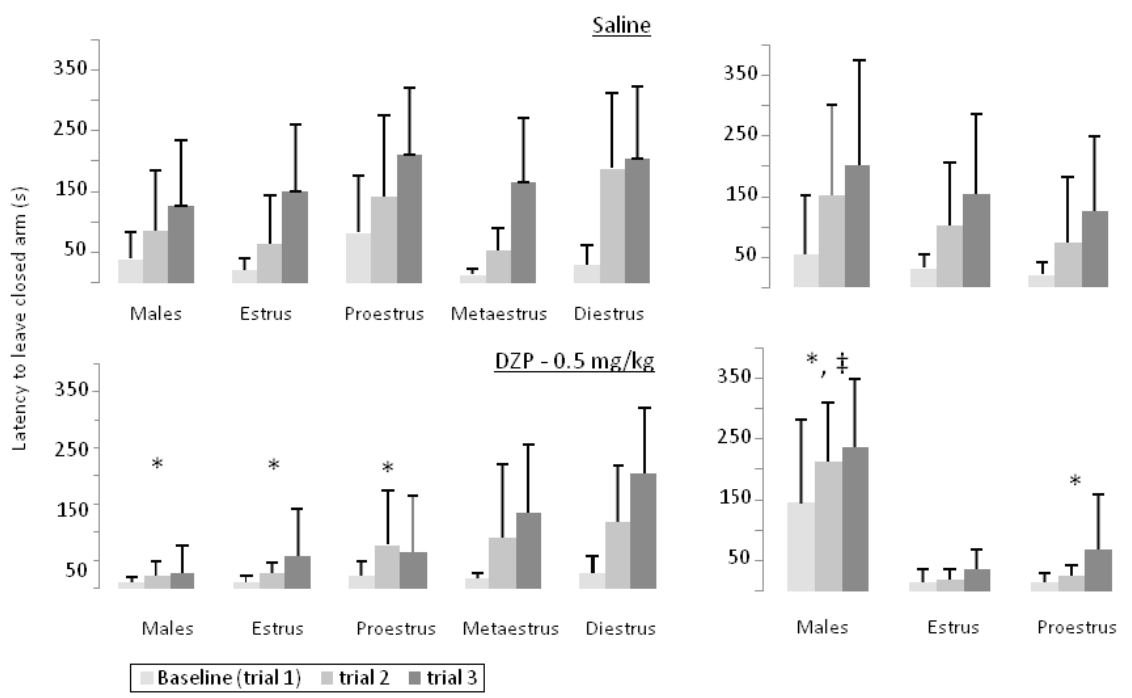

$\underline{\text { DZP }-1.0 \mathrm{mg} / \mathrm{kg}}$
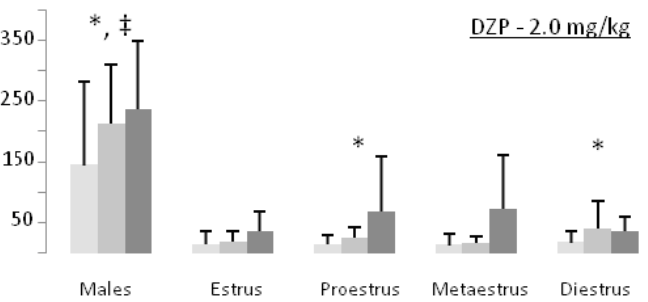

Figure 1. Estrous cycle modulates inhibitory avoidance acquisition in the elevated T-maze and affects diazepam sensitivity in that task. The charts represent mean ( \pm S.E.M.) latencies to leave the closed arm of the elevated T-maze as a function of gender and estrous cycle phase, as well as diazepam dose. Asterisks $(*)$ represent differences within a given dose, while the double dagger symbol ( $\ddagger$ ) represents differences against controls (0.9\% saline).

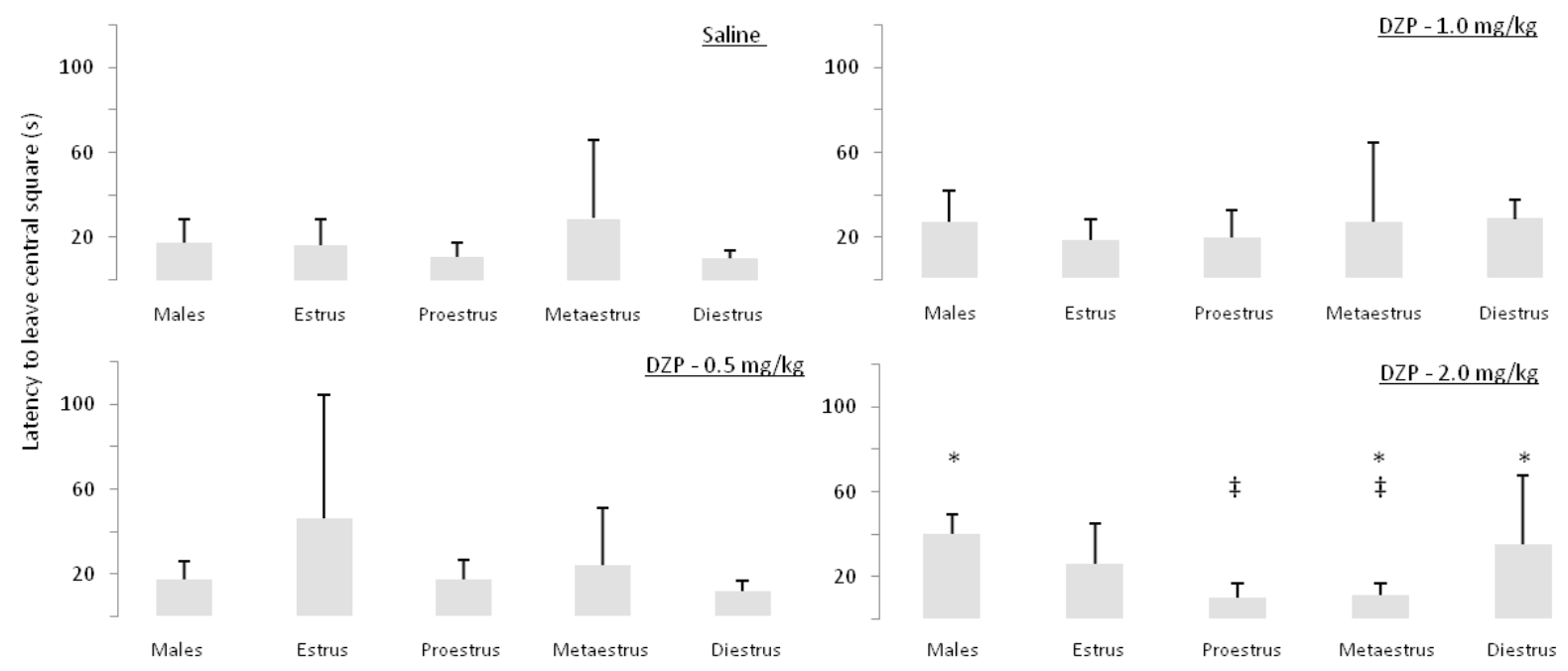

Figure 2. Estrous cycle does not have an effect in escape trials in the elevated T-maze, and diazepam effects are detectable only at higher doses, suggesting motor impairment. The charts represent mean ( \pm S.E.M.)latencies to leave the central square of the elevated T-maze as a function of gender and estrous cycle phase, as well as diazepam dose. Asterisks $\left(^{*}\right)$ represent differences within a given dose, while the double dagger symbol $(\ddagger)$ represents differences against controls ( $0.9 \%$ saline). 
or hormonal status $\left(\mathrm{F}_{[4,140]}=.223, \mathrm{p}=.2230\right.$ were found; however, a statistically significant interaction between both factors was observed $\left(\mathrm{F}_{[12,138]}=1.857, \mathrm{p}=.045\right)$.

\section{Discussion}

The present article tested the influence of estrous cycle phase on the anxiolytic and panicolytic-like effects of diazepam, using the elevated T-maze, a rodent anxiety model. The results indicate a modulatory action of gender and hormonal status on the effects of diazepam in the elevated T-maze, evident in anxietylike (inhibitory avoidance) but not fear-like behaviors (escape), in the diestrus and proestrus phases, correspondent to an increase in the circulating levels of estrogen present in female rats' organisms. These results are consistent with available evidence regarding increased anxiety and estrogen levels (Bitran \& Dowd, 1995; Díaz-Véliz, Alarcón, Espinoza, Dussabaut, \& Mora, 1997; Díaz-Véliz, Soto, Dussabaut, \& Mora, 1989; Gouveia et al., 2004; Gouveia \& Morato, 2002). Females in diestrus and proestrus also presented reduced latency times in inhibitory avoidance trials in relation to males and females in metaestrus and diestrus, suggesting an anxiolytic effect of progesterone also consistent with the literature (Frye et al., 2000; Frye \& Walf, 2002; Frye, Walf, Rhodes, \& Harney, 2004; Guilinello et al., 2001; Rhodes \& Frye, 2001; Smith et al., 1998). The significant increases in latency times on males' inhibitory avoidance trials are proportional to the dose of diazepam, suggesting not a neuromodulatory phenomenon, but a sedative and ataxic effect of this benzodiazepine.

The differential result in anxiety - but not panic - is consistent with the observation that estrous cycle modulates responses to anxiogenic stimuli in the elevated T-maze, but not to panicogenic stimuli (Gouveia et al., 2004). It also indicates that the site of action is not restricted to the ventromedial hypothalamic nucleus, dorsal periaqueductal gray area or medial nucleus of the amygdala, since facilitation of GABA activity in these regions produces effects on panic measures in the elevated T-maze (Bueno, Zangrossi, Nogueira, Soares, \& Viana, 2005; Bueno et al., 2007; Herdade, Strauss, Zangrossi, \& Viana, 2006). Exposure to the inhibitory avoidance task of this model increases Fos-like immunoreactivity in the medial amygdaloid nucleus, anterior hypothalamic nucleus and raphe nuclei, while the escape task increases Fos-like immunoreactivity in the basolateral amygdaloid nucleus and in the dorsal periaqueductal gray area (Silveira et al., 2001). Accordingly, the modulation of diazepam sensitivity by estrogen, being anxiety-related, is likely to have happened at the level of the raphe nuclei, a set of structures presenting surface and nuclear estrogen and progestin receptors (Alves, Weiland, Hayashi, \& McEwen, 1998). Estrogen and progesterone modulate the firing of raphe neurons (Robichaud \& Debonnel, 2004, 2005), and serotonergic neurons in the raphe have been associated with the modulation of anxiety-like behavior (Graeff, 2002; Graeff, Viana, \& Mora, 1997). Interestingly, the immunoreactivity of estrogen and progestin receptors in the raphe does not coincide with tryptophan hydrolase immunoreactivity, suggesting that the targets of steroid modulation of raphe serotonergic activity are not serotonergic neurons (Alves et al., 1998).

Such differences between males and females in diestrus and proestrus may be related to a modulatory action of estrogen over the $\mathrm{GABA}_{\mathrm{A}}$ receptor complex and the benzodiazepine subunit. This action would be manifested by a diminished efficacy of diazepam during diestrus and proestrus - precisely the phases of the estrous cycle that present increased estrogen activity.

One possible mechanism involves the activation of membrane-associated estrogen receptors, whose response is mediated by the second messenger protein kinase C (Kelly \& Levin, 2001; Kelly \& Wagner, 1999; Le Saux \& Di Paolo, 2005). PKC would phosphorylate $\mathrm{GABA}_{\mathrm{A}}$ receptors, decreasing the efficacy of benzodiazepines. This hypothesis is strengthened by the observation that phosphorylation of these receptors through the action of PKC determines sensitivity to neurosteroids (Fancsik et al., 2000), together with evidence that mice knocked out for the $\varepsilon$ isoform of PKC are more sensitive to the modulation of chloride uptake by allopregnanolone, alphaxalone, and preganolone (Hodge et al., 2002) and data on the behavioral and neurochemical effects of alcohol and benzodiazepines (Choi, Wang, Dadgar, Chang, \& Messing, 2002; Hodge et al., 1999; Olive, Mehmert, Messing, \& Hodge, 2000; Olive, Mehmert, Nannini, Camarini, Messing, \& Hodge, 2001).

Another possibility is that activation of nuclear $\beta$ estrogen receptors in raphe neurons could down-regulate $\mathrm{GABA}_{\mathrm{A}}$ receptor density, an effect that was observed in the preoptic area and in the bed nucleus of the stria terminalis of female rats (Herbison \& Fénelon, 1995). The relative contribution of effects mediated through genomic modulation of $\mathrm{GABA}_{\mathrm{A}}$ receptors and effects mediated through receptor phosphorylation to the effects of estrogen on behavior is yet undetermined, and it should be considered that these two mechanisms may be operating in association (Brandon, Uren, Kittler, Wang, Olsen, \& Parker, 1999; Kumar, Sieghart, \& Morrow, 2002; Moss \& Smart, 1996). The association between the effects of diazepam and progesterone levels is indicated by the effectiveness of the drug (i.e., diminished latency times) in the estrus phase, when this hormone is found at its peak level, and is probably due to the direct action of progesterone and its metabolites on allosteric sites of the $\mathrm{GABA}_{\mathrm{A}}$ receptor. Diazepam seems also to be effective in the metaestrus phase, where no hormonal activity is found in the female rats' organisms. 


\section{References}

Alves, S.E., Weiland, N.G., Hayashi, S., \& McEwen, B.S. (1998). Immunocytochemical localization of nuclear estrogen receptors and progestin receptors within the rat dorsal raphe nucleus. Journal of Comparative Neurology, 391, 322-334.

Archer, J. (1975). Rodent sex differences in emotional and related behavior. Behavioral Biology, 14, 451-479.

Berezhnoy, D., Gravielle, M.C., \& Farb, D.H. (2007). Pharmacology of the GABA receptor. In: Sibley, D.R., Hanin, I., Kuhar, M., \& Skolnick, P. (Eds.), Handbook of contemporary neuropharmacology (v.1, pp. 465-568). Hoboken: John Wiley \& Sons, Inc

Bitran, D., \& Dowd, J.A. (1995). Ovarian steroids modify the behavioral and neurochemical responses of the central benzodiazepine receptor. Psychopharmacology, 125, 65-73.

Blanchard, D.C., \& Blanchard, R.J. (1988). Ethoexperimental approaches to the biology of emotion. Annual Review of Psychology, 39, 43-68.

Brandon, N.J., Uren, J.M., Kittler, J.T., Wang, H., Olsen, R.W., \& Parker, P.J. (1999). Subunit-specific association of protein kinase c and the receptor for activated c kinase with GABA type a receptors. Journal of Neuroscience, 19, 9228-9234.

Bueno, C.H., Zangrossi Jr., H., Nogueira, R.K., Soares, V.P., \& Viana, M.d.B. (2005). Panicolytic-like effect induced by the stimulation of GABA and gaba ${ }_{b}$ receptors in the dorsal periaqueductal grey of rats. European Journal of Pharmacology, 516, 239-246.

Bueno, C.H., Zangrossi Jr., H., \& Viana, M.d.B. (2007). GABA benzodiazepine receptors in the ventromedial hypothalamic nucleus regulate both anxiety and panic-related defensive responses in the elevated t-maze. Brain Research Bulletin, 74, 134-141.

Choi, D.-S., Wang, D., Dadgar, J., Chang, W.S., \& Messing, R.O. (2002). Conditional rescue of protein kinase c e regulates ethanol preference and hypnotic sensitivity in adult mice. Journal of Neuroscience, 22, 9905-9911.

Costa, E. (1998). From GABA receptor diversity emerges a unified vision of GABAergic inhibition. Annual Review of Pharmacology and Toxicology, 38, 321-350.

Dellovade, T., Zhu, Y., \& Pfaff, D. (1999). Thyroid hormones and estrogen affect oxytocin gene expression in hypothalamic neurons. Journal of Neuroendocrinology, 11, 1-10.

Díaz-Véliz, G., Alarcón, T., Espinoza, C., Dussabaut, N., \& Mora, S. (1997). Ketanserin and anxiety levels: Influences of gender, estrous cycle, ovariectomy and ovarian hormones in female rats. Pharmacology, Biochemistry and Behavior, 58, 637-642.

Díaz-Véliz, G., Benavides, M.S., Butrón, S., Dussabaut, N., \& Mora, S. (1999). Behavior effects of dopamine agonists and antagonists: Influences of estrous cycle, ovariectomy and estrogen replacement in rats. Pharmacology, Biochemistry and Behavior, 62, 21-29.

Díaz-Véliz, G., Soto, V., Dussaubat, N., \& Mora, S. (1989). Influence of the estrous cycle, ovariectomy and estradiol replacement upon the acquisition of conditioned avoidance responses in rats. Physiology \& Behavior, 125, 65-73.

Fancsik, A., Linn, D.M., \& Tasker, J.G. (2000). Neurosteroid modulation of GABA ipscs is phosphorylation dependent. Journal of Neuroscience, 20, 3067-3075.

Fanselow, M.S., \& Lester, L. (1988). A functional behavioristic approach to aversively motivated behavior: Predatory imminence as a determinant of the topography of defensive behavior. In: Bolles, R.C., \& Beecher, M.D. (Eds.), Evolution and learning (pp. 185-211). Hillsdale: Erlbaum.

Fernández-Guasti, A., Martínez-Mota, L., Estrada-Camarenas, E., Contreras, C.M., \& Lórez-Rubalcava, C. (1999). Chronic treatment with desipramine induces an estrous cycle-dependent anxiolyticlike action in burying behavior, but not in the elevated plus-maze test. Pharmacology, Biochemistry and Behavior, 63, 13-20.

Frye, C.A., Petralia, S.M., \& Rhodes, M.E. (2000). Estrous cycle and sex differences in performance on anxiety tasks coincide with increases in hippocampal progesterone and 3a,5a-thp. Pharmacology, Biochemistry and Behavior, 67, 587-596.

Frye, C.A., \& Walf, A.A. (2002). Changes in progesterone metabolites in the hippocampus can modulate open field and forced swim test behavior of proestrous rats. Hormones and Behavior, 41, 306-315.

Frye, C.A., Walf, A.A., Rhodes, M.E., \& Harney, J.P. (2004). Progesterone enhances motor, anxiolytic, analgesic, and antidepressant behavior of wild-type mice, but not those deficient in type 1,5-a-reductase. Brain Research, 1004, 116-124.

Gouveia Jr., A., dos Santos, U.D., Felisbino, F.E., Afonseca, T.L.,
Antunes, G., \& Morato, S. (2004). Influence of the estrous cycle on the behavior of rats in the elevated t-maze. Behavioural Processes, 67, 167-171.

Gouveia Jr., A., \& Morato, S. (2002). Influência do ciclo estral sobre o desempenho de ratos no labirinto em cruz elevado. Interação em Psicologia, 6, 141-148.

Graeff, F.G. (2002). On serotonin and experimental anxiety. Psychopharmacology, 163, 467-476.

Graeff, F.G., Netto, C.F., \& Zangrossi Jr., H. (1998). The elevated t-maze as an experimental model of anxiety. Neuroscience and Biobehavioral Reviews, 23, 237-246.

Graeff, F.G., Viana, M.d.B., \& Mora, P.O. (1997). Dual role of 5-ht in defense and anxiety. Neuroscience and Biobehavioral Reviews, 21, 791-799.

Graeff, F.G., Viana, M.d.B., \& Tomaz, C. (1993). The elevated t-maze, a new experimental model of anxiety and memory: Effect of diazepam. Brazilian Journal of Medical and Biological Research, 26, 67-70.

Guilinello, M., Gong, Q.H., Li, X., \& Smith, S.S. (2001). Short-term exposure to a neuroactive steroid increases $a_{4}$ GABA $_{\mathrm{A}}$ receptor subunit levels in association with increased anxiety in the female rat. Brain Research, 910, 55-66.

Hamon, M., Goetz, C., Euvrad, C., Pasqualini, C., LeDafniet, M., Kerdelhue, B., et al. (1983). Biochemical and functional alterations of central GABA receptors during chronic estradiol treatment. Brain Research, 279, 141-152.

Herbison, A.E. (1997). Estrogen regulation of GABA transmission in rat preoptic area. Brain Research Bulletin, 44, 321-326.

Herbison, A.E., \& Fénelon, V.S. (1995). Estrogen regulation of GABA receptor subunit expression in preoptic area and bed nucleus of the stria terminalis of female rat brain. Journal of Neuroscience, 15, 2328-2337.

Herdade, K.C.P., Strauss, C.V.A., Zangrossi Jr., H., \& Viana, M.d.B. (2006). Effects of medial amygdala inactivation on a panic-related behavior. Behavioral Brain Research, 172, 316-323.

Hodge, C.W., Mehmert, K.K., Kelley, S.P., McMahon, T., Haywood, A., Olive, M. F., et al. (1999). Supersensitivity to allosteric GABA(a) receptor modulators and alcohol in mice lacking pkcepsilon. Nature Neuroscience, 2, 997-1002.

Hodge, C.W., Raber, J., McMahon, T., Walter, H., Sanchez-Perez, A.M., Olive, M.F., et al. (2002). Decreased anxiety-like behavior, reduced stress hormones, and neurosteroid supersensitivity in mice lacking protein kinase c epsilon. Journal of Clinical Investigations, 110, 1003-1010.

Kelly, M.J., \& Levin, E.R. (2001). Rapid actions of plasma membrane estrogen receptors. Trends in Endocrinology and Metabolism, 12, 152-156.

Kelly, M.J., \& Wagner, E.J. (1999). Estrogen modulation of g-protein-coupled receptors. Trends in Endocrinology and Metabolism, 10, 369-374.

Koksma, J.J., van Kesteren, R.E., Rosahl, T.W., Zwart, R., Smit, A.B., Luddens, H., et al. (2003). Oxytocin regulates neurosteroid modulation of GABA(a) receptors in supraoptic nucleus around parturition. Journal of Neuroscience, 23, 788-797.

Krezel, W., Dupont, S., Krust, A., Chambon, P., \& Chapman, P.F. (2001). Increased anxiety and synaptic plasticity in estrogen receptor b-deficient mice. Proceedings of the National Academy of Sciences USA, 98, 122278-122282.

Kumar, S., Sieghart, W., \& Morrow, A.L. (2002). Association of protein kinase $c$ with $\mathrm{GABA}_{\mathrm{A}}$ receptors containing a1 and a4 subunits in the cerebral cortex: Selective effects of chronic ethanol consumption. Journal of Neurochemistry, 82, 110-117.

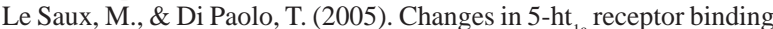
and g-protein activation in the rat brain after estrogen treatment: Comparison with tamoxifen and raloxifene. Journal of Psychiatry and Neuroscience, 30, 110-117.

Maggi, A., \& Perez, J. (1984). Progesterone and estrogens in rat brain: Modulation of GABA receptor activity. European Journal of Pharmacology, 103, 165-168.

Markus, E.J., \& Zecevic, M. (1997). Sex differences and estrous cycle changes in hippocampus-dependent fear conditioning. Psychobiology, 25, 246-252.

Maswood, S., Stewart, G., \& Uphouse, L. (1995). Gender and estrous cycle effects of the 5-ht agonist, 8-oh-dpat, on hypothalamic serotonin. Pharmacology, Biochemistry and Behavior, 51, 807-813.

Maswood, S., Truitt, W., Hotema, M., Caldarola-Pastuszka, M., \& Uphouse, L. (1999). Estrous cycle modulation of extracellular serotonin in mediobasal hypothalamus: Role of the serotonin transporter and terminal autoreceptors. Brain Research, 831, 145-154. 
McKernan, R.M., \& Whiting, P. (1996). Which GABA ${ }_{A}$ receptor subtypes really occur in the brain? Trends in Neuroscience, 19, 139-143.

Mora, S., Dussabaut, N., \& Díaz-Véliz, G. (1996). Effects of the estrous cycle and ovarian hormones on behavioral indices of anxiety in female rats. Psychoneuroendocrinology, 21, 609-620.

Morgan, M.A., Schulking, J., \& Pfaff, D.W. (2004). Estrogens and nonreproductive behaviors related to activity and fear. Neuroscience and Biobehavioral Reviews, 28, 55-63.

Moss, S.J., \& Smart, T.G. (1996). Modulation of amino acid-gated ion channels by protein phosphorylation. International Review of Neurobiology, 39, 1-52.

Nomikos, G.G., \& Spyraki, C. (1988). Influence of oestrogen on spontaneous and diazepam-induced exploration of rats in an elevated plus-maze. Neuropharmacology, 27, 691-696.

Ogawa, S., Chan, J., Gustafsson, J.-Å., Korach, K.S., \& Pfaff, D.W. (2003). Estrogen increases locomotor activity in mice through estrogen receptor alpha: Specificity for the type of activity. Endocrinology, 144, 230-239.

Olive, M.F., Mehmert, K.K., Messing, R.O., \& Hodge, C.W. (2000). Reduced operant ethanol self-administration and in vivo mesolimbic dopamine responses to ethanol in pkce-deficient mice. European Journal of Neuroscience, 12, 4131-4140.

Olive, M.F., Mehmert, K.K., Nannini, M.A., Camarini, R., Messing, R.O., \& Hodge, C.W. (2001). Reduced ethanol withdrawal severity and altered withdrawal-induced c-fos expression in various brain regions of mice lacking protein kinase c-epsilon. Neuroscience, 103, 171-179.

Olsen, R.W. (2002). GABA. In: Davis, K.L., Charney, D., Coyle, J.T., \& Nemeroff, C. (Eds.), Neuropsychopharmacology: The fifth generation of progress (pp. 159-168). New York: American College of Neuropsychopharmacology.

Österlund, M., Gustafsson, J.-Å., Keller, E., \& Hurd, Y.L. (2000). Estrogen receptor b (erb) messenger ribonucleic acid (mrna) expression within the human forebrain: Distinct distribution pattern to era mrna. Journal of Clinical Endocrinology and Metabolism, 85, 3840-3846.

Österlund, M., Halldin, C., \& Hurd, Y.L. (2000). Effects of chronic 17b-estradiol treatment on the serotonin 5-ht ${ }_{1 \mathrm{a}}$ receptor mrna and binding levels in the rat brain. Synapse, 35, 39-44.

Österlund, M., Kuiper, G.G.J.M., Gustafsson, J.-Å., \& Hurd, Y.L. (1998). Differential distribution and regulation of estrogen receptor-a and -b mrna within the female rat brain. Molecular Brain Research, 54, 175-180.

Puia, G., Dučič, I., Vicini, S., \& Costa, E. (1993). Does neurosteroid modulatory efficacy depend on GABA receptor subunit composition? Receptors and Channels, 1, 135-142.

Puia, G., Santi, M.R., Vicini, S., Pritchett, D.B., Purdy, R.H., Paul, S.M., Seeburg, .PH., \& Costa, E. (1990). Neurosteroids act on recombinant human GABAAreceptors. Neuron, 4, 759-765. Rhodes,
M.E., \& Frye, C.A. (2001). Inhibiting progesterone metabolism in the hippocampus of rats in behavioral estrus decreases anxiolytic, and enhances exploratory and anti-nociceptive behaviors. Cognitive and Affective Behavioral Neuroscience, 1, 287-296.

Robichaud, M., \& Debonnel, G. (2004). Modulation of the firing activity of female dorsal raphe nucleus serotonergic neurons by neuroactive steroids. Journal of Neuroendocrinology, 182, 11-21.

Robichaud, M., \& Debonnel, G. (2005). Oestrogen and testosterone modulate the firing activity of dorsal raphe nucleus serotonergic neurons in bothmale and femalerats. Journal of Neuroendocrinology, 17, 179-185

Rubinow, D.R., Schmidt, P.J., \& Roca, C.A. (1998). Estrogenserotonin interactions: Implications for affective regulation. Biological Psychiatry, 44, 839-850.

Schmitt, U., Lüddens, H., \& Hiemke, C. (2000). Behavioral effects of GABA receptor stimulation and GABA-transporter inhibition. Pharmacology, Biochemistry and Behavior, 65, 351-356.

Sfikakis, A., Spyraki, C., Sitaras, N., \& Varonos, D. (1978). Implication of the estrous cycle on conditioned avoidance behavior in the rat. Physiology \& Behavior, 21, 441-446.

Shors, T.J., Lewczyk, C., Pacynski, M., Mathew, P.R., \& Pickett, J. (1998). Stages of estrous mediate the stress-induced impairment of associative learning in the female rat. Neuroreport, 9, 419-423.

Shughrue, P.J., \& Merchenthaler, I. (2001). Distribution of estrogen receptor beta immunoreactivity in the rat central nervous system. Journal of Comparative Neurology, 436, 64-81.

Silveira, M.C.L., Zangrossi Jr., H., Viana, M.d.B., Silveira, R., \& Graeff, F.G. (2001). Differential expression of fos protein in the rat brain induced by performance of avoidance or escape in the elevated t-maze. Behavioural Brain Research, 126, 13-21.

Smith, S.S., Gong, Q.H., Li, X., Moran, M.H., Bitran, D., Frye, C.A., et al. (1998). Withdrawal from 3a-oh-5a-pregnan-20-one using a pseudopregnancy model alters the kinetics of hippocampal $\mathrm{GABA}_{\mathrm{A}}$-gated current and increases the GABA receptor a4 subunit in association with increased anxiety. Journal of Neuroscience, 18, 5275-5284.

Treit, D., \& Fundytus, M. (1989). Thigmotaxis as a test for anxiolytic activity in rats. Pharmacology, Biochemistry and Behavior, 31, 959-962.

Viana, M.d.B., Tomaz, C.A.B., \& Graeff, F.G. (1994). The elevated t-maze: A new animal model of anxiety and memory. Pharmacology, Biochemistry and Behavior, 49, 549-554.

Zangrossi Jr., H., \& Graeff, F.G. (1996). Behavioral validation of the elevated t-maze, a new animal model of anxiety. Brain Research Bulletin, 44, 1-5.

Zhu, W.J., \& Vicini, S. (1997). Neurosteroids prolong GABA channel deactivation by altering kinetics of desensitized states. Journal of Neuroscience, 17, 4022-4031. 